\title{
クロマチンリモデリング因子による小腸吸収細胞 遺伝子発現誘導機構
}

(平成 21 年度日本栄養・食糧学会奨励賞)

$$
\text { 望 月 和 樹*,1 }
$$

(2009 年 9 月 17 日受付； 2009 年 10 月 14 日受理)

\begin{abstract}
要旨：ビタミン A 結合タンパク質 CRBPII および脂肪酸結合タンパク質 L-FABP の空腸における遺伝子発現 は, ラットの哺乳中期に増大し, 二糖類水解醳素スクラーゼ・イソマルターゼ複合体 (SI) および果糖輸送担 体 (GLUT5) の遺伝子発現は, 哺乳中期から哺乳後期に増大する。本研究では, CRBPII および L-FABP の遺 伝子の発現増大は核内受容体 PPAR $\alpha$ を介しており, GLUT5 遺伝子の発現増大は甲状腺ホルモンおよびグル ココルチコイドホルモンの核内受容体（TR $\alpha-1, \mathrm{GR})$ により調節されることを明らかにした。さらに，栄養 素・ホルモンのシグナルがこれら遺伝子の上流域・転写領域上に扔けるヒストンのアセチル化ならびにクロ マチンリモデリング因子 $\mathrm{CBP} / \mathrm{p} 300$ の結合を増大させることを明らかにした。これらの知見は, 栄養素・ホ ルモンが, 核内転写因子の活性化因子㧍よびクロマチン構造を劇的に変動させる鍵因子として働き, 空腸消 化吸収関連遺伝子の転写を調節することを示したものである。
\end{abstract}

キーワード : 栄養素, 空腸, 核内転写因子, ヒストンアセチル化, クロマチンリモデリング因子

げっ歯類小腸の形態と遺伝子発現は, 徐々に離乳が進 行する生後 2-4 週間（哺乳中期から離乳後）において急 激に変化する (本研究において, 出生後 0-12 日を哺乳前 期，13-21 日を哺乳中期，22-27 日を哺乳後期，それ以降 を離乳後と定義した)。この時期には, 食餌組成が糖質の 少ないもの（母乳）から比較的多いもの（固形食）へと 切替わる1)。それゆえ, 哺乳中期から哺乳後期にかけて 起こるげっ歯類小腸の形態や遺伝子発現の変化は，母乳 中の脂肪の多い食事に対応するものだけではなく，その 後の糖質中心の固形食への移行に対応するためのもので あると考えられる。

これまでの研究によると, 小腸管腔から流入する脂肪 酸の輸送に関与する肝臟型脂肪酸結合タンパク質 （L-FABP）の空腸における遺伝子発現は, 母乳中の脂肪 が大量に流入する哺乳中期に増大する2)。一方，著者た ちの研究室では, L-FABP だけではなく, ビタミンAの 転送に関与する細胞性レチノール結合タンパク質タイプ II（CRBPII）の遺伝子発現が, 成熟ラット空腸において 脂肪摃取により増大することを明らかにした ${ }^{3)}$ 。脂肪摂 取に伴うこれらの mRNA 転写の増大機構には, 脂肪酸を 直接リガンドとする核内受容体であるペルオキシソーム 増殖因子活性化受容体 (PPAR) が関与することが知られ
ている。PPARには, 三つのサブタイプ PPAR $\alpha, \operatorname{PPAR} \delta$, PPAR $\gamma$ が知られている。空腸ではPPAR $\alpha$ なら゙に PPAR $\delta$ が強く発現している ${ }^{4)}$ 。著者らは, 成熟期のラッ 卜空腸において, 脂肪摂取時には L-FABP および CRBPII の遺伝子発現の増大とともに PPAR $\alpha$ の遺伝子発現が増 大するのに対し, PPAR $\delta$ の遺伝子発現が減少することを 明らかにした4)。これらの結果は, 成熟期のげっ歯類の 空腸における L-FABP ならびにCRBPII の遺伝子発現 が，PPAR $\alpha$ によ正に, PPAR $\delta$ にり負に制御を受け る可能性を示唆している。また, 母乳には大量の脂肪が 含まれている (Figure 1A)。それゆえ, 母乳の脂肪を構成 している脂肪酸により PPARが活性化され, 哺乳期にお ける脂肪ならびにビタミン A の吸収を効率よく行うた めに, これらの遺伝子発現を増大させている可能性があ ると考えられる。

一方，小腸には糖質の終末消化と吸収に関与する二糖 類水解醩素と糖輸送担体が発現している。小腸微絨毛膜 上に存在し, デンプンの加水分解物やショ糖の消化に関 与するスクラーゼ・イソマルターゼ複合体 (SI) のよう な二糖類水解酵素ならびにグルコース・ガラクトースの 輸送体である $\mathrm{Na}^{+} /$グルコース共輸送体 (SGLT1), 果糖 の輸送担体 GLUT5 が発現している。基底膜側には, グ

* 連絡者・別刷請求先 (E-mail：wazyumochi@hotmail.com)

1 静岡県立大学食品栄養科学部栄養生命学科（422-8526 静岡市駿河区谷田 52-1） 
A)

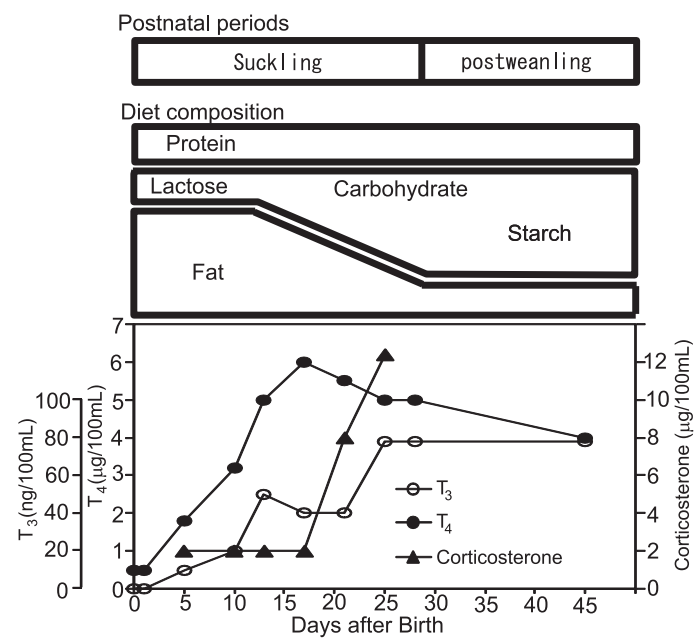

C)

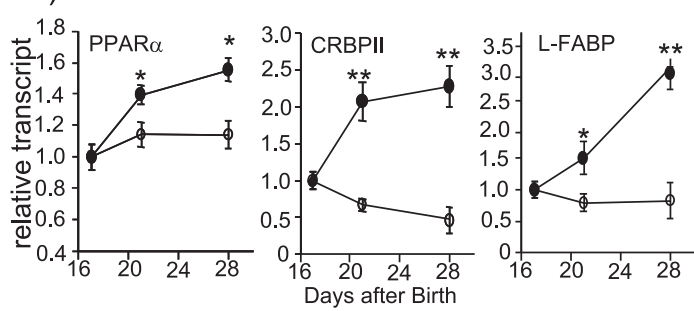

D)

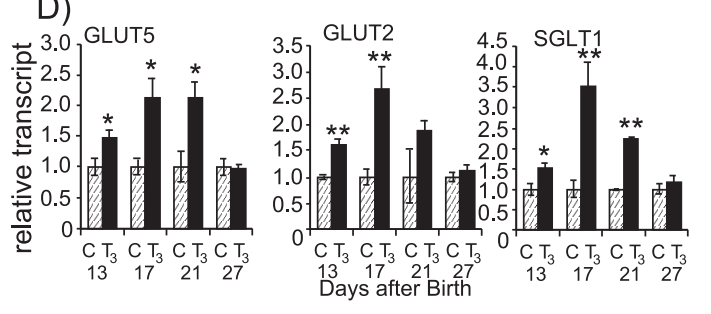

B)
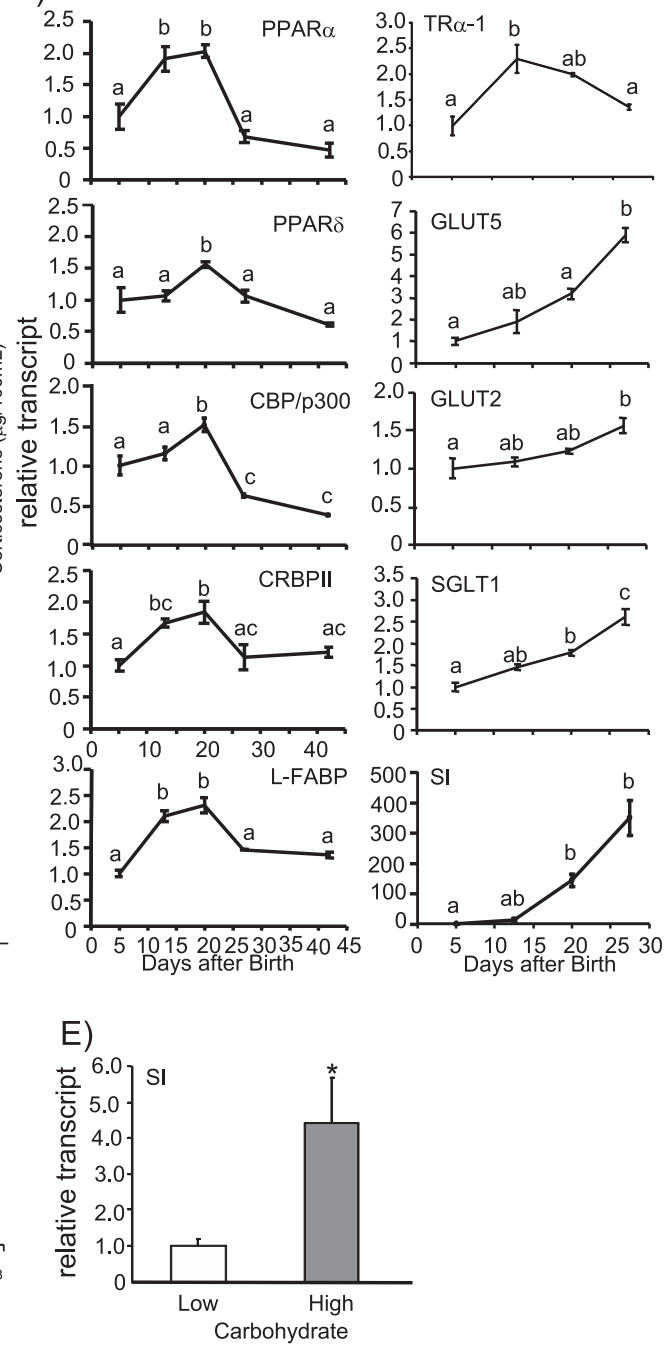

Figure 1 A) Changes of diet composition and serum concentrations of thyroid hormones and glucocorticoid hormone in postnatal development of the rats. The data are drew from a review of Koldovsky. ${ }^{1)}$ B) Postnatal changes of jejunal gene expression in Sprague-Dawley (SD) rat jejunum. $\bullet, \bigcirc$ indicate groups fed a high fatand low fat-diets, respectively. C) Jejunal gene expression changes by feeding rats a high- or low-fat diet for 4 and 11 days in weanling SD rats at 17 days of age. D) Changes on jejunal hexose transporters gene expressions by $\mathrm{T}_{3}$ injection (i.p. once a day for 6 days with $0.3 \mu \mathrm{g} / \mathrm{g}$ body weight $\mathrm{T}_{3}$ ) in postnatally developing SD rats. E) Jejunal expression change of SI gene in adult C57BL/6J mice fed a high- or low-carbohydrate-diet for 7 days. Each mRNA level was normalized to $18 \mathrm{~S}$ rRNA mRNA (B-D) or $\beta$-actin mRNA abundance (E). Data represent the means \pm SEM $(B-E)$. a, b, c; Values not sharing a common superscript are significantly different $(p<0.05)$ from one another by Tukey's multiple range test. Asterisks indicate significant differences as compared with the levels in rat fed a low fat-diet (C) or control rats (D) (Student's $t$-test, ${ }^{*} p<0.05,{ }^{* *} p<0.01$ ).

ルコース，ガラクトース，果糖を門脈に輸送する輸送体 GLUT2 が発現している。これらをコードする遺伝子の空 腸における発現は, げっ歯類では哺乳中期から哺乳後 期・離乳後にかけて顕著に増大することが知られてい る5)。ま。た，これら遺伝子の発現は，デンプン，ショ 糖，果糖により増大することが知られている778)。さら に, 哺乳中期には, 血中の甲状腺ホルモンならびにグル ココルチコイドホルモンの濃度が急激に増大する （Figure 1A）ので, 上記の遺伝子の発現がこれらのホル
モンにより調節される可能性も考えられる。これらのホ ルモンはそれぞれ，甲状腺ホルモン受容体 (TR) ならび グルココルチコイドホルモン受容体 $(\mathrm{GR})$ と結合し, 標 的遺伝子の発現を増大させる。小腸には TRの二つのサ ブタイプTR $\alpha$ ならびに TR $\beta$ が発現し, GR も発現するこ とが確認されている ${ }^{910)}$ 。それゆえ, 空腸における糖輸送 体の哺乳中期から哺乳後期・離乳後における遺伝子の発 現増大は, TR および GR を介して起こる可能性が考えら れる。 
最近の研究によると, 哺乳中期にみられるような細胞 の分化に伴う劇的な遺伝子発現の変動には, 転写因子だ けでなく, ヒストンのアセチル化, メチル化, リン酸化 などのヒストン修飾が関与していることが明らかとなっ ている。特に, 転写が盛んなユークロマチン領域ではヒ ストン H3, H4 が高度にアセチル化されていることか ら, ヒストン H3, H4 のアセチル化が転写制御において 重要な役割を果たすものと考えられている11)。さらに, アセチル化したヒストンは, アセチル化ヒストンに結合 するブロモドメインをもつクロマチンリモデリング因子 と結合し, 転写複合体を標的遺伝子上に集合させること により転写を正に調節している。特に，クロマチンリモ デリング因子であり，コアクチベーターと呼ばれるタン パク質群は, 核内転写因子と結合し, ヒストンタンパク 質のアセチル化を誘導し, 核内転写因子のシグナルを強 く増幅することが知られている12)。しかしながら, 哺乳 中期から哺乳後期の空腸における脂肪・ビタミン A お よび糖の消化吸収関連遺伝子の転写因子, ならびにクロ マチンリモデリング因子を介した調節機構は, 解明され ていない。

そこで, 本研究では, 哺乳中期から哺乳後期の発達過 程における栄養素・ホルモンによる空腸消化吸収関連遺 伝子の発現調節機構を, 核内転写因子, ヒストンの修飾 ならびにクロマチンリモデリング因子に焦点を当てて検 討した。

\section{哺乳中期のラットの空腸における遺伝子発現変動と 栄養素・ホルモンによる影響}

ラット哺乳中期から哺乳後期 (13 日から 27 日) では, 母乳から脂肪を多く摂取するが, 離乳の進行に伴って 徐々に糖質の摂取量が増大する。また，哺乳中期では， 甲状腺ホルモン $\left(\mathrm{T}_{3}, \mathrm{~T}_{4}\right)$ ならびにグルココルチコイドホ ルモン（コルチコステロン）の血中濃度が劇的に増大す ることが報告されている $(\text { Figure } 1 \mathrm{~A})^{1)}$ 。そこで，まず， この哺乳期から離乳後までの空腸において, CRBPII, L-FABP の遺伝子発現ならびにこれらの転写に関与する ことが想定される核内受容体 PPAR $(\operatorname{PPAR} \alpha, \operatorname{PPAR} \delta)$ の遺伝子発現が変動するかを調べた。その結果, CRBPII, L-FABP の遺伝子は，ともに，母乳を多く摂取している 哺乳中期（13，20日）にかけて高い発現を示し, 哺乳後 期である 27 日, 離乳後である 42 日ではその発現が顕著 に低下することが明らかとなった (Figure 1B)。PPAR $\alpha$ 遺伝子は, 13 日から 20 日にかけて最も発現が高かった。 一方, $\operatorname{PPAR} \delta$ の遺伝子発現は, 20 日に一時的な増大がみ られたものの PPAR $\alpha$ ほどの変動がみられなかった (Figure 1B) ${ }^{13)}$ 。次に, 著者らは, PPARのシグナルを強 く伝えると想定されるクロマチンリモデリング因子であ るコアクチベーター $\mathrm{CBP} / \mathrm{p} 300^{14)}$ の小腸における遺伝子 発現が哺乳期に変動するかを調べることにした。CBP お よび p300 は，核内受容体と結合できる LXXLL モチーフ
をもち，ヒストンアセチル化酵素活性をもつタンパク質 である ${ }^{14)}$ 。ラットにおいては, CBP/p300の遺伝子は同 定されてなかったために, まず, 両遺伝子の核内受容体 結合ドメインの cDNA をクローニングした ${ }^{14)}$ 。本研究で は, CBP ならびに p300 は相同性が高く, 両者をノーザ ンブロット法では分離して測定することが不可能なた め, $\mathrm{CBP} / \mathrm{p} 300$ として測定した。その結果, $\mathrm{CBP} / \mathrm{p} 300$ の 遺伝子発現は, 13 日から 20 日にかけて最も発現が高 かった (Figure 1B) ${ }^{15)}$ 。これらの結果から, 哺乳期から離 乳後のラットの空腸における CRBPII, L-FABP の遺伝子 の発現は, 授乳中期に最も高く, それらの発現は, 核内 転写因子 PPAR $\alpha$ ならびにクロマチンリモデリング因子 $\mathrm{CBP} / \mathrm{p} 300$ の発現と強く相関することが明らかとなっ た。次に, 哺乳中期である 17 日に強制的に仔ラットを離 乳させ, 高脂肪食あるいは低脂肪食を 4 日間もしくは 11 日間与えたところ, 高脂肪食摂取群の空腸における PPAR $\alpha$, CRBPII, L-FABP の遺伝子発現は, 低脂肪食摂取 群に比べて有意に高かった (Figure 1C) ${ }^{13)}$ 。CBP/p300の 空腸における遺伝子発現も高脂肪食摂取群で増大し た ${ }^{15)}$ 。さらに, 哺乳後期 (27日) のラットに, 母乳中に 多く含まれる中鎖脂肪酸 (カプリル酸), 長鎖不飽和脂肪 酸（オレイン酸，リノール酸，アラキドン酸）を 4 日間 経口強制投与したところ, CRBPII, L-FABP, PPAR $\alpha$, $\mathrm{CBP} / \mathrm{p} 300$ の遺伝子発現が顕著に誘導された ${ }^{13) 15) 。 ま た, ~}$ 出生後 25 日に強制離乳させたラットにPPAR $\alpha$ の活性 化剂であるクロフィブレートを 1 日 1 回 3 日間, 経口投 与した場合も, 27 日に強制離乳させたラットにPPAR $\alpha$ の合成リガンド Wy14,643 を 1 日 1 回 4 日間, 経口投与 した場合も, CRBPII, L-FABP の遺伝子発現が誘導され た (4)13) これらのことは, 哺乳中期のラット空腸における CRBPII, L-FABP, PPAR $\alpha, \mathrm{CBP} / \mathrm{p} 300$ の遺伝子発現の増 大は, 母乳中に含まれる脂肪酸を介して起こっているこ とを示唆している。

一方, 糖の輸送体 (GLUT5, GLUT2, SGLT1) ならび にSI の遺伝子の発現は, 哺乳中期から哺乳後期にかけて 顕著に増大した (Figure 1B) ${ }^{16) 17)}$ 。これらの遺伝子発現に 関与すると想定されている転写因子 caudal type homeobox $(\mathrm{Cdx})-2$, hepatocyte nuclear factor $(\mathrm{HNF})-1$, グルコ コルチコイドホルモン受容体 (GR) の遺伝子発現は顕著 な変動を示さなかったが, 甲状腺ホルモン受容体 (TR) のサブタイプである TR $\alpha-1$ の遺伝子発現は, 糖輸送体な らびにSIの遺伝子の発現が急激に増大する 13 日から 20 日にかけて高まっていた (Figure 1B)。さらに, 13, 17, 21, 27 日齢のラットにあらかじめ 1 日 1 回, 計 6 回, 解剖日まで $\mathrm{T}_{3}$ を腹腔内に投与したところ, 小腸にお ける糖輸送体の遺伝子発現が $13,17,21$ 日齢のラットで は増大した (Figure 1D) ${ }^{16)}$ 。さらに, 著者らは, 離乳期 のラットの空腸に果糖を還流させると GLUT5 遺伝子の 発現が増大し, $T_{3}$ をあらかじめ腹腔内投与しておくと, この発現がさらに増大することを発見した ${ }^{18)}$ 。一方, 離 
乳後のマウスに高糖質（デンプン）食を与えたところ, 核内転写因子 Cdx-2, HNF-1 の遺伝子発現は変動しな かったが (データは示さず), SI 遺伝子の発現が顕著に 増大した (Figure 1E $)^{7)}$ 。これらのことから, げっ歯類の 哺乳中期における空腸の糖輸送体は, 血中の $\mathrm{T}_{3}$ 濃度の増 大に伴う空腸の TR $\alpha-1$ の発現変動を介して調節されて いる可能性が考えられ，一方，哺乳後期から離乳後の空 腸における SI 遺伝子の発現は, 食餌性の糖質により正に 調節されることが考えられた。さらに，著者らは，げっ 歯類の哺乳中期から哺乳後期の空腸では，他の多くの消 化吸収関連遺伝子の発現が変動していることをマイクロ アレイ解析で観察している ${ }^{19)}$ 。それらの遺伝子群がそれ ぞれどのような食事因子あるいはホルモンにより変動す るかは，今後の課題である。

\section{空腸 CRBPII， L-FABP 遺伝子の PPAR $\alpha$ を介した 発現増大機構のモデル細胞における検証}

Figure 1 で示すように, 空腸における CRBPII および L-FABP 遺伝子の哺乳中期における発現増大は, 核内受 容体 PPAR $\alpha$ ならびにコアクチベーター CBP/p300 遺伝 子の発現に強く相関する。そこで, 小腸様 Caco-2 細胞に おいて, CRBPII ならびにL-FABPの遺伝子発現が $\mathrm{PPAR} \alpha$ および CBP/p300を介して調節を受けるかを検 討した。まず，酵母の転写因子 GALA リガンド結合ドメ

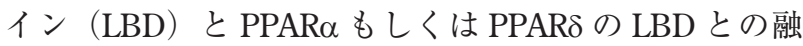
合タンパク質を発現するプラスミドを作製し, Caco-2 細 胞にトランジェントトランスフェクョンにより導入し, 融合タンパク質を発現させた。同時に, SV40 プロモー ターの上流に GALAの結合エレメントをもつルシフェ ラーゼレポータープラスミドをトランスフェクションし た。この系は, 哺乳類ワンハイブリット法と呼ばれ, GAL4-LBD に融合したPPAR-LBD タンパク質が細胞内 で強制的に GAL4 結合エレメントに結合し，リガンドに より転写複合体の形成が促進されるとルシフェラーゼ夕 ンパク質の発現が誘導される。すなわち，ルシフェラー ゼ活性を測定することで転写複合体形成能を測定するこ とが可能となる方法である。Figure $2 \mathrm{~A}$ に示すように, Caco-2 細胞において炭素数 18-20 個で, 二重結合が 3-5 個（ $\alpha$-リノレン酸から EPA までの脂肪酸）にかけての脂 肪酸が強くPPAR $\alpha$ の転写複合体形成能を促進した。一 方, $\operatorname{PPAR} \delta$ による転写複合体形成能は, PPAR $\alpha$ よ顕 著に低かった (Figure $2 \mathrm{~A})^{20) 21)}$ 。さらに, 著者らは, 炭素 数 18-20 個で, 二重結合 3-5 個にかけての脂肪酸は, $\mathrm{PPAR} \alpha$ の立体構造変化を誘導するが, $\operatorname{PPAR} \delta$ の立体構 造の変化は誘導しないこともあわせて明らかにし た ${ }^{20) 21)}$ 。これらのことは, 小腸様 Caco-2 細胞において, 炭素数 18-20 個で, 二重結合 3-5 個にかけての脂肪酸は, 強くPPAR $\alpha$ を活性化し, 転写複合体の形成を促すが, これらの脂肪酸によっては, PPAR $\delta$ は活性化を受けにく いことを示している。近年, これらの転写複合体形成能
は, クロマチンリモデリング因子であり，コアクチベー ターとして知られる $\mathrm{CBP} / \mathrm{p} 300$ が強く仲介することが 知られている。著者らは, CBP および 300 の空腸回腸 内分布を詳細に調べ，両遺伝子は空腸と回腸のいずれに おいても発現することを確認した。さらに, p300が小腸 様 Caco-2 細胞において, CBP より強く PPARのシグナ ルを伝えることも明らかとなった ${ }^{14)}$ 。そこで, GALA-LBD と PPAR-LBD の融合タンパク質を発現するプラスミド, GALA の結合エレメントをもつルシフェラーゼレポー タープラスミドならびに GALA の活性化ドメイン $(\mathrm{AD})$ とコアクチベーター p300 の核内受容体結合ドメインと の融合タンパク質を発現するプラスミドベクターを Caco-2 細胞に導入し, リノール酸, アラキドン酸で 2 日 間培養後ルシフェラーゼ活性を測定した。この系は, 哺 乳類ツーハイブリット法と呼ばれ, GALA 結合エレメン ト上にある PPAR-LBD にp300 が結合するとその融合夕 ンパク質である $\mathrm{AD}$ が SV40を活性化し，ルシフェラー ゼを発現という原理を利用した系であり，この方法を用 いると細胞内における PPAR-p300 の結合を検出するこ とが可能となる。Figure $2 \mathrm{~B}$ に示すように, Caco-2 細胞 内における PPAR $\alpha$ と 300 の結合は, リノール酸により 高まる傾向があり, アラキドン酸によって有意に増大し たが, PPAR $\delta$ と 300 の結合は, これらの脂肪酸によっ て誘導されることはなかった（Figure $2 \mathrm{~B}$ )。さらに，著 者らは, DNA とタンパク質の結合を in vitro で確認する ゲルシフト法を行った。ゲルシフト法とは, ${ }^{32} \mathrm{P}$ のラジオ アイソトープで標識したDNAとタンパク質と反応さ せ, アクリルアミド電気泳動 (PAGE) で分離する方法 である。タンパク質が ${ }^{32} \mathrm{P}$ 標識した DNA に結合すると， PAGE 上の移動度が減少するために DNA-タンパク質の 結合が確認できる方法である。この方法により, CRBPII 遺伝子上流域にみられる PPAR 応答領域 (PPRE) である RXRE，RE3 だけでなく L-FABP, HMG-CoA シンターゼ (HMG), Acyl-CoAオキシダーゼ (ACO) のPPREに $\mathrm{PPAR} \alpha-\mathrm{RXR} \alpha$ ならびに $\mathrm{PPAR} \delta$-RXR $\alpha$ ヘテロ 2 量体が結 合することが確認され，さらに，リノール酸ならびにア ラキドン酸の添加により, それらへテロ 2 量体の結合が 増大することが明らかとなった (Figure $2 \mathrm{C})^{21)}$ 。さらに, 著者らは, PPAR $\alpha-R X R \alpha$ ヘテロ 2 量体の PPREへの結合 は，炭素数 18-20 個で，二重結合 3-5 個にかけての脂肪

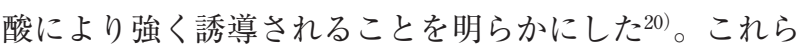
の結果より, 小腸様 Caco-2 細胞において, PPAR $\alpha$ の転 写活性化能は炭素数 18-20 個で, 二重結合 3-5 個の脂肪 酸により強く誘導され，この転写活性化能は p300によ り仲介される可能性が高いことが示唆された。一方, $\operatorname{PPAR} \delta$ は, 転写複合体形成能は弱いが, PPAR $\delta$-RXR $\alpha$ へ テロ 2 量体の PPREへの結合がリノール酸, アラキドン 酸により促進されることから, PPAR $\alpha$ に対する弱いドミ ナントネガティブ作用をもつ可能性が示唆された。さら に, コンフルエント $100 \%$ に達して間もない Caco-2 細胞 


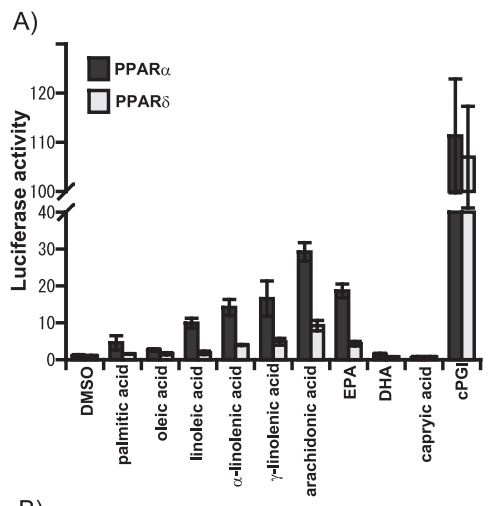

C)
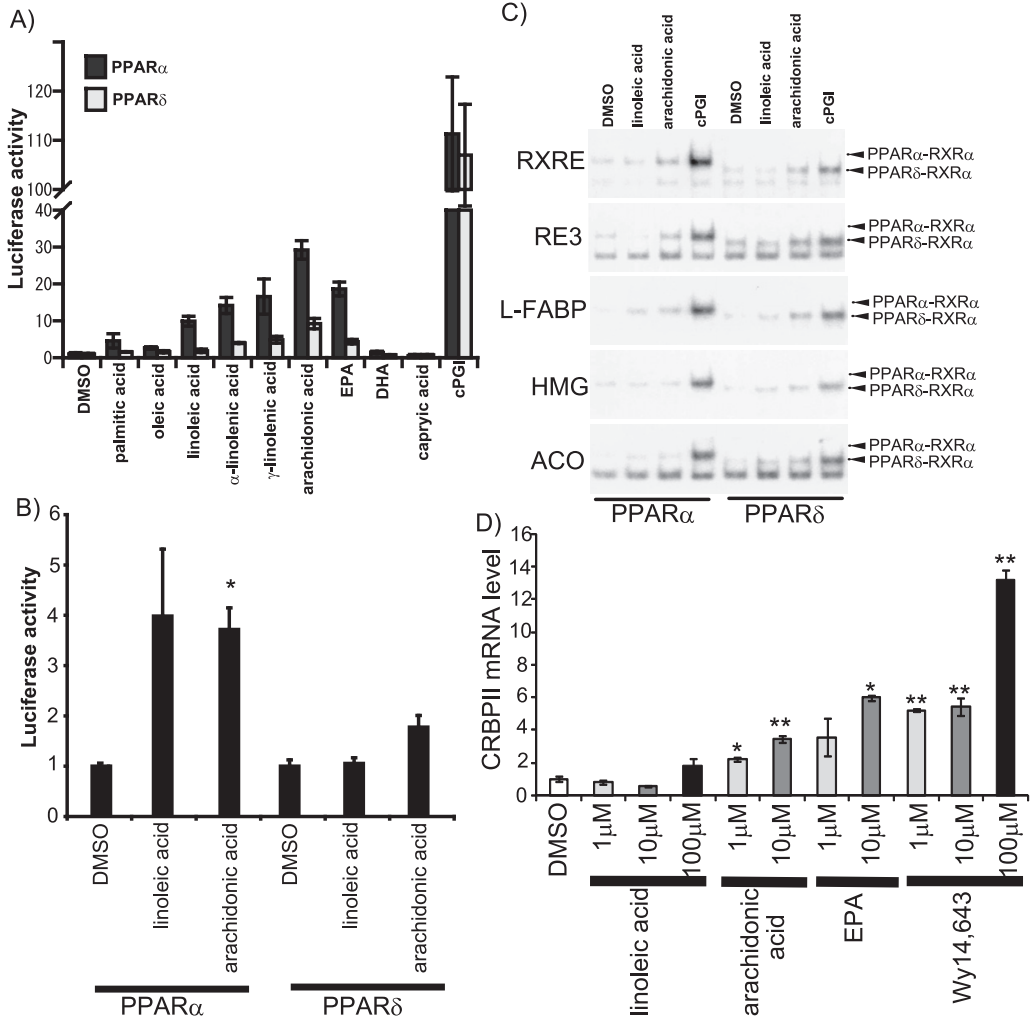

Figure 2 A) Mammalian one hybrid assays for PPARs in Caco-2 cells. The plasmids containing a GAL4-fused LBD (pBIND) of PPAR $\alpha$ or PPAR $\delta$ was co-transfected into Caco-2 cells with GAL4-responsive luciferase reporter plasmids. B) Mammalian two hybrid assays for PPARs-p300 binding in Caco-2 cells. Caco-2 cells were co-transfected with pG5-Luc, either pBIND-PPAR $\alpha$-LBD or pBIND-PPAR $\delta$-LBD, and a plasmid containing a GALAfused $\mathrm{AD}$ ( $\mathrm{pACT}$ ) of p300. After transfection, cells were incubated with fatty acids or synthetic ligands for $48 \mathrm{~h}(\mathrm{~A}$, B). C) Electoropholeic mobility shift assays (EMSAs) for binding of PPARs-RXR $\alpha$ heterodimers to various PPREs. In vitro translated PPAR $\alpha$ and RXR $\alpha$ were mixed with various ${ }^{32} \mathrm{P}$-labeled PPREs in the absence/presence of fatty acids or cPGI, a synthetic ligand for both PPAR $\alpha$ and PPAR $\delta$ D) Effects of polyunsaturated fatty acids on the CRBPII mRNA levels in Caco-2 cells with 100\% confluency treated with fatty acids or Wy14,643 for 5 days. Each mRNA level was normalized to $18 \mathrm{~S}$ rRNA mRNA abundance. Data represent the means \pm SEM $(A, B, D)$. Asterisks indicate significant differences as compared with vehicle by Dunnet's test $\left({ }^{*} p<0.05, \quad{ }^{* *} p<0.01\right)$.

に 5 日間, 脂肪酸もしくはPPAR $\alpha$ の合成リガンド Wy14,643 を投与したところ, CRBPII 遺伝子の発現が, $100 \mu \mathrm{M}$ のリノール酸によって誘導される傾向があり, 1-10 $\mu \mathrm{M}$ のアラキドン酸, $10 \mu \mathrm{M} \mathrm{EPAならびに1-}$ $100 \mu \mathrm{M}$ の Wy14,643 で顕著に誘導されることが確認さ れた (Figure 2D)。これらの結果と Figure 1B，Cの結果 をまとめると, 哺乳中期における CRBPII および L-FABP の, 核内転写因子 PPAR $\alpha$ ならびにクロマチンリモデリ ング因子 $\mathrm{CBP} / \mathrm{p} 300$ の遺伝子発現増大は，不飽和脂肪酸 による PPAR $\alpha$ と 300 の結合増大による転写複合体の 形成促進によりもたらされるものと考えられた。

\section{TR $\alpha$ および GR を介した空腸 GLUT5 遺伝子 発現増大のモデル細胞における検証}

Figure 1 の結果より, 空腸糖輸送体の哺乳中期から哺 乳後期にかけての遺伝子発現増大には, 甲状腺ホルモン
により活性化された甲状腺ホルモン受容体 TR $\alpha-1$ が関 与している可能性が考えられる。先行研究において, 小 腸様 Caco-2/TC7 細胞では, GLUT5 遺伝子の発現が $\mathrm{T}_{3}$ の投与により増大すること, さらに, GLUT5 遺伝子上流 域には甲状腺ホルモン応答領域 (TRE) が存在している ことが示されている22)。さらに，哺乳初期にグルココル チコイドホルモンを腹腔内投与すると空腸における GLUT5 遺伝子の発現が増大することが他のグループの 研究により示されている ${ }^{10)}$ 。それゆえ, 糖輸送体遺伝子 の空腸における発現増大には, グルココルチコイドホル モン受容体 GRの関与も想定される。また, Caco-2 細胞 の遺伝子発現の多くは, 細胞の分化に伴う $\mathrm{p} 44 / 42$ mitogen activated protein (MAP) キナーゼの不活性化に

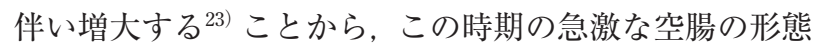
変化に伴う糖輸送体の遺伝子発現の増大には, ホルモン だけではなく, p44/42 MAP キナーゼの不活性化が関与 
A)

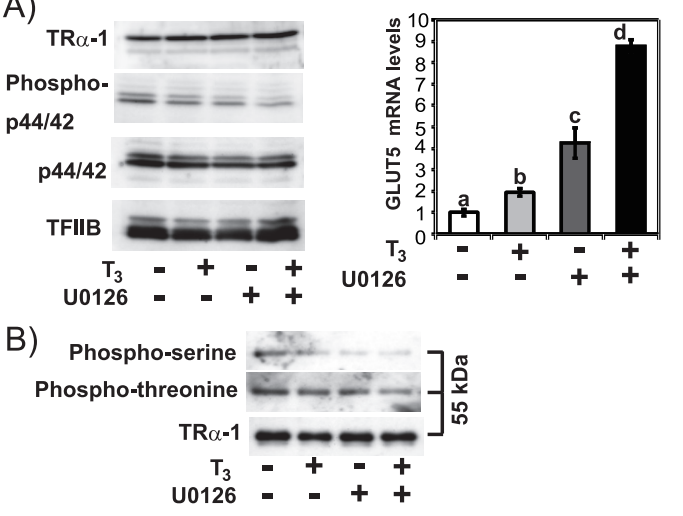

C)
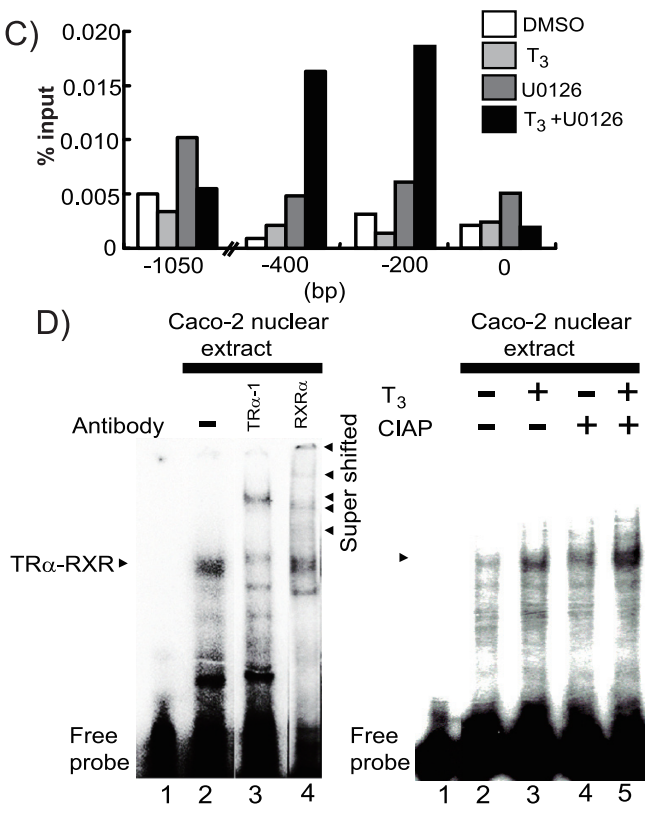

E)
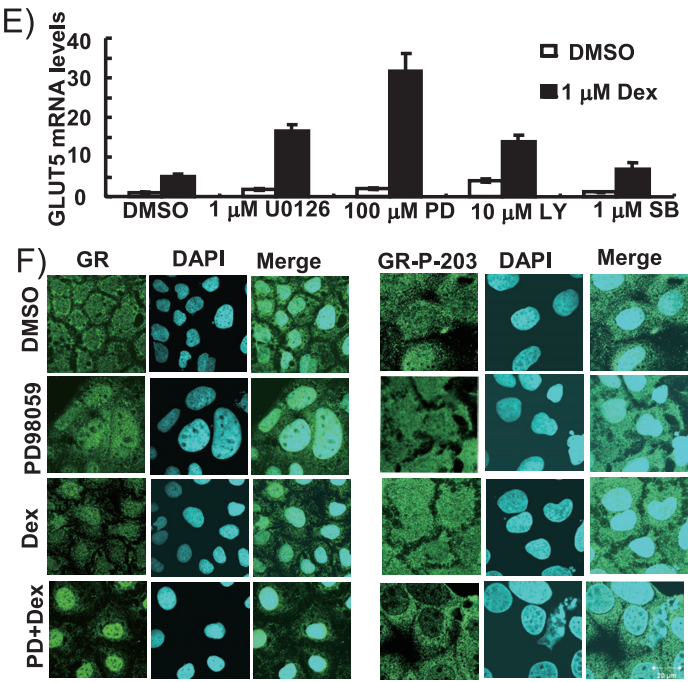

G)
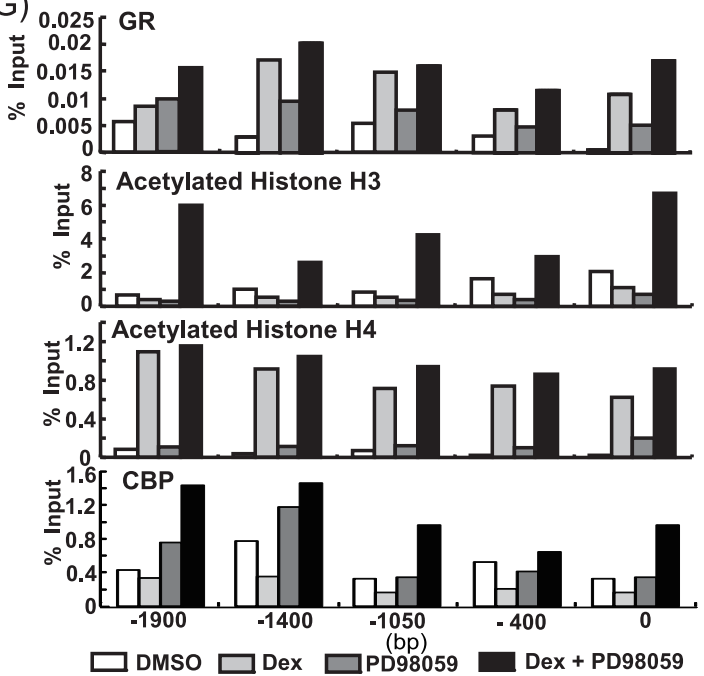

Figure 3 A) Caco-2 cells with $80 \%$ confluency were treated with $1 \mu \mathrm{M} \mathrm{T}_{3}$ and/or $1 \mu \mathrm{M}$ U0126. Immunoblots were analyzed for TR $\alpha$, phosphorylated form of p44/44 MAPK, total p44/44 MAPK and TFIIB. Northern blots were analyzed for GLUT5. B) Immunoblots for phosho-serine, phosho-threonine and TR $\alpha-1$ in proteins of Caco-2 precipitated by TR $\alpha-1$ antibody. C) Chromatin immunoprecipitation (ChIP) assays for TR $\alpha-1$ in Caco-2 cells treated with $1 \mu \mathrm{M} \mathrm{T}_{3}$ and $1 \mu \mathrm{M}$ U0126. D) EMSAs for binding of TR $\alpha$-1-RXR heterodimer to ${ }^{32}$ P-labeled GLUT5-TRE using nuclear extracts from Caco-2 cells with $80 \%$ conflency with antibodies or calf intestinal alkaline phosphatase (CIAP). E) mRNA levels of GLUT5 in Caco-2 cells treated with several kinase inhibitors with/without $1 \mu \mathrm{M}$ Dex for $48 \mathrm{~h}$. F) Immunofluorescence staining for total GR and phosho-GR at Ser203 in Caco-2 cells treated with $50 \mu \mathrm{M}$ PD98059 and/or $1 \mu \mathrm{M}$ Dex. Staining for each antibody, DNA staining, and overlap between the two signals were visualized as a green color, a blue color and yellow, respectively. G) ChIP assays for GR and acetylated histones H3 and H4 on the GLUT5 promoter/enhancer region in Caco-2 cells treated with $50 \mu \mathrm{M}$ PD98059 and/or $1 \mu \mathrm{M}$ Dex. ChIP signals were normalized to input signals. Values represent means \pm SEM. The mRNA levels for GLUT5 were normalized to the corresponding $18 \mathrm{~S}$ rRNA levels (A, E).

している可能性も考えられる。そこで, 小腸様 Caco-2 細 胞に $\mathrm{T}_{3}$ もしくは,グルココルチコイドホルモンのアゴニ ストであるデキサメタゾン（以下 Dex）を, p44/42 MAP キナーゼの阻害剤とともに投与し, GLUT5 遺伝子の発現 を調べた。まず，コンフルエント $80 \%$ の Caco-2 細胞に, $1 \mu \mathrm{M}$ の $\mathrm{T}_{3}$ あるいは $1 \mu \mathrm{M} の \mathrm{p} 44 / 42 \mathrm{MAP}$ キナーゼ (MEK1/2）の阻害剤であるU0126を，2 日間，それぞれ
単独あるいは同時に投与した。その結果， $\mathrm{T}_{3}$ あるいは U0126 の単独投与によっても GLUT5 遺伝子の発現は増 大したが, $\mathrm{T}_{3}$ と U0126 を同時に投与することにより相乗 的な増大がみられた (Figure 3A)。このときの Caco-2 細 胞の核内に打ける TR $\alpha-1$ のセリンならびにスレオニン 残基のリン酸化は，顕著に抑制されていた (Figure 3B)。 さらに, in vivoに扔ける DNA-タンパク質の結合を PCR 
法により観察するクロマチン免疫沈降法を行ったとこ ろ, $\mathrm{T}_{3}$ と U0126 共投与時には GLUT5 遺伝子上流域の TRE (GLUT5-TRE) 近傍において TR $\alpha$-1 の結合が顕著に 増大することを発見した (Figure 3C)。さらに, Caco-2 細胞から抽出した核タンパク質をin vitroで GLUT5TREの合成オリゴヌクレオチドとインキュベートし, GLUT5-TRE に結合するタンパク質を調べたところ（ゲ ルシフト法), TR $\alpha-1-R X R \alpha$ ヘテ 2 量体が GLUT5-TRE

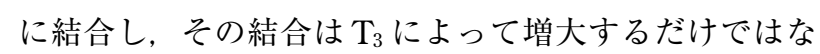
く, ウシ小腸アルカリフォスファターゼ (CIAP) による 脱リン酸化処理によっても増大し, 特に $\mathrm{T}_{3}$ と CIAP の共 投与により劇的に増大することが観察された（Figure 3D)。これらのことから, 小腸様 Caco-2 細胞における $\mathrm{T}_{3}$ ならびに $\mathrm{p} 44 / 42 \mathrm{MAP}$ キナーゼ阻害剤共投与時におけ る GLUT5 遺伝子の発現誘導には, $T_{3}$ だけではなく, $\mathrm{p} 44 / 42 \mathrm{MAP}$ キナーゼの不活性化に伴う TR $\alpha-1$ タンパク 質の脱リン酸化を介した TR $\alpha-1$ タンパク質の活性化が 関与している可能性が示唆された ${ }^{24)}$ 。

次に, コンフレント $80 \%$ の Caco-2 細胞に, $1 \mu \mathrm{M}$ の Dex とともにさまざまなキナーゼの阻害剤（p44/42 MAP キナーゼ阻害剂 U0126 $1 \mu \mathrm{M}, \quad$ PD98059 $100 \mu \mathrm{M}$, PI3 キナーゼ阻害剂 LY29402 $10 \mu \mathrm{M}$, p38 MAP キナーゼ 阻害剤 SB203580 $1 \mu \mathrm{M}$ ）を 2 日間共投与してみた（これ
らキナーゼ阻害剤の至適濃度は，それぞれ 0.1-100 $\mu \mathrm{M}$ の濃度で GLUT5 遺伝子発現を観察することによって決 定した $\left.{ }^{25)}\right)$ 。その結果, $\mathrm{p} 44 / 42 \mathrm{MAP}$ キナーゼ阻害剤と Dexを同時に投与したときには, GLUT5 遺伝子の発現 が顕著に増大した (Figure 3E)。さらに, 著者らは, Dex 投与時に GR211 番目のセリン残基がリン酸化されるこ とを Caco-2 細胞で確認するとともに, GRの核内移行が Dex と PD98059 の共投与により顕著に促進されること を発見した。また, Dex と PD98059の共投与により，核 内の GR203 番目のセリン残基のリン酸化が顕著に減少 することを発見した (Figure $3 \mathrm{~F})^{25)}$ 。著者らはさらに,

Dex と PD98059 の共投与時には, GR, アセチル化ヒス トンならびにクロマチンリモデリング因子 CBP の GLUT5 遺伝子上流域への結合が顕著に高いことを, クロ マチン免疫沈降法を用いて明らかにした（Figure 3G）。 これらの結果から, 小腸様 Caco-2 細胞における $\mathrm{p} 44 / 42$ MAP キナーゼ阻害剤ならびにDex 共投与時における GLUT5 遺伝子の発現増大には, グルココルチコイドホル モンによる GRの 211 番目セリン残基のリン酸化ならび に $\mathrm{p} 44 / 42 \mathrm{MAP}$ キナーゼの阻害による GR の 203 番目の セリン残基の脱リン酸化に伴う GR の核内移行が関与し ていると考えられ, さらに GLUT5 遺伝子上流域におけ るヒストンのアセチル化の増大に伴うクロマチンリモデ

\section{A) SI gene}

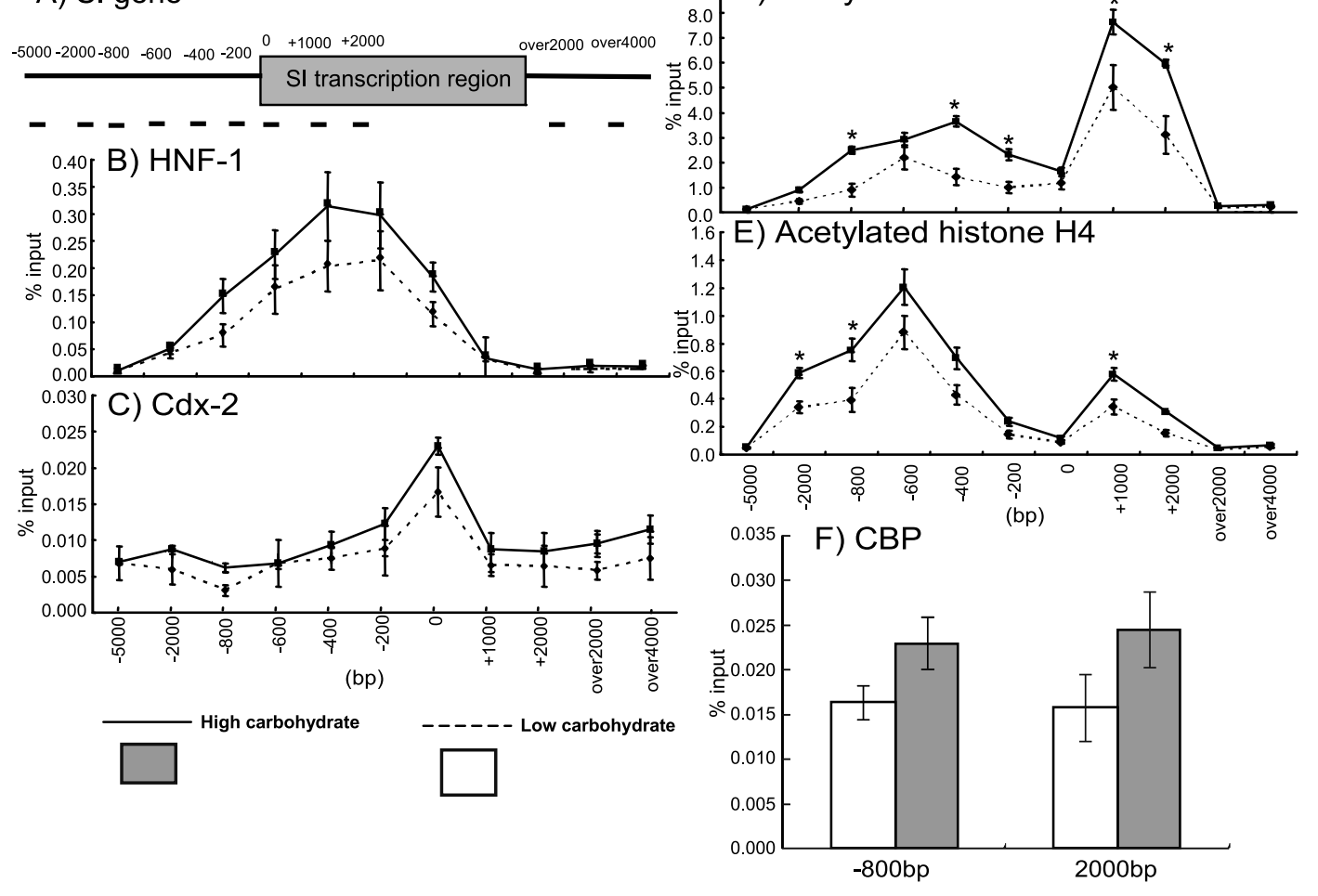

Figure 4 ChIP assays for HNF-1 (B), Cdx-2 (C), acetylated histone H3 (D), acetylated histone H4 (E) and $\mathrm{CBP}(\mathrm{F})$ in adult $\mathrm{C} 57 \mathrm{BL} / 6 \mathrm{~J}$ mice fed a high carbohydrate- or a low carbohydrate-diet for one week. Primer pairs used for ChIP assays (A). ChIP signals were normalized to input signals. Asterisks indicate significant differences by Student's $t$-test versus levels in mice fed the low carbohydrate-diet $\left({ }^{*} p<0.05\right)$. 
リング因子 CBP の集合が関与していると考えられた ${ }^{25)}$ 。

\section{高糖質（デンプン）食捸取時に増大する空腸 SI 遺伝子の発現増大機構の検証}

Figure 1B, E に示すように, 空腸 SI 遺伝子の発現は, 哺乳中期から哺乳後期にかけて急激に増大し, 離乳後に 高糖質（デンプン）食摂取により誘導される。著者らは, クリプトから絨毛への分化に伴うSI 遺伝子の発現に転 写因子 $\mathrm{Cdx}-2$ が関与することを明らかにしている ${ }^{26)}$ 。さ らに，著者らは，クリプトから絨毛への分化時にみられ る SI 遺伝子の発現増大ならびにラットの発達に伴う哺 乳中期から哺乳後期における SI 遺伝子の発現増大には, いずれも SI 遺伝子上のヒストンのアセチル化が関与し

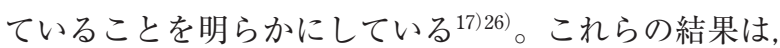
哺乳中期から離乳後にかけての SI 遺伝子の発現増大は, 流入するデンプンによりもたらされる可能性を示してお り, さらにその遺伝子発現は, 転写因子である $\mathrm{Cdx}-2$ お よび HNF-1 の結合, さらにヒストンのアセチル化により 調節される可能性を示している。そこで，高糖質食を摂 取させたマウスの空腸における SI 遺伝子の発現増大に おける転写因子 ( $\mathrm{Cdx}-2, \mathrm{HNF}-1)$ およびヒストンのアセ チル化の役割をクロマチン免疫沈降法により調べたとこ ろ, SI 遺伝子への転写因子 HNF-1 および $\mathrm{Cdx}-2$ の結合 は，高糖質食群では低糖質食群と比べて高まる傾向に あった（Figure 4B, C)。さらに，高糖質食を摂取させた マウスでは，低糖質食群に比べて，SI 遺伝子上のヒスト ン H3 および H4 のアセチル化が, プロモーター/エンハ ンサー領域と転写領域のいずれでも有意に増大していた (Figure 4D, E)。SI 遺伝子へのクロマチンリモデリング 因子 CBP の結合は, 高糖質食群では低糖質食群と比べて 高まる傾向にあった (Figure 4F)。これらの結果より, マ ウス空腸における SI 遺伝子の高糖質食摂取による発現 増大は, ヒストンのアセチル化の増大に伴うクロマチン リモデリング因子 $\mathrm{CBP}$ の結合増大がその一因であるこ とが想定された7)。さらに，著者らは，空腸における SI 遺伝子の果糖摂取時における発現増大ならびに SGLT1 遺伝子の高糖質食摂取時における発現増大にも, これら の遺伝子上のヒストンのアセチル化の増大が関与してい

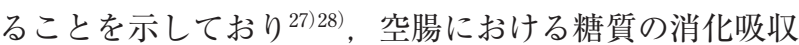
関連遺伝子の発現調節には，ヒストンのアセチル化が重 要であることと考えられる。

\section{結語}

以上に示したように，げっ歯類の出生後の発達過程に おける空腸の脂質ならびに糖質の消化吸収関連遺伝子の 栄養素・ホルモンによる発現変動は, 栄養素・ホルモン のシグナルによる転写因子の活性化だけではなく，遺伝 子の上流域・転写領域に結合するヒストンタンパク質の アセチル化の増大に伴うクロマチンリモデリング因子の 結合促進が関与していることが明らかにされた。
本稿を終えるにあたり，栄誉ある日本栄養・食糧学会 奨励賞を授与されたことに対し，選考委員の先生方をは じめ, 関係の諸先生方に厚くご御礼申し上げます。本研 究は, 静岡県立大学食品栄養科学部栄養生理学研究室で 行われたものです。本研究のご指導・ご助言をいただい た静岡県立大学食品栄養科学部の合田敏尚教授, 浜松大 学健康プロデュース学部の高瀬幸子教授, 長崎県立大学 看護栄養学部の駿河和仁准教授に深くお礼申し上げま す。卒業研究でさまざまな実験手法をご指導いただいた 静岡大学理学部の山内清志教授, NIH におけるポスドク として勤務していたときにさまざまな実験手法，概念を ご指導いただいた尾里啓子博士（Lab Chief）に, 深謝申 し上げます。最後に，これまでご指導ならびにご協力を 賜りました諸先生方と共同研究者の皆様に感謝申し上げ ます。

\section{文献}

1) Koldovsky O (1985) Response of the gastrointestinal tract to premature weaning in experimental animals. Pediatrics 75 : 199-206.

2) Gordon JI, Elshourbagy N, Lowe JB, Liao WS, Alpers DH, Taylor JM (1985) Tissue specific expression and developmental regulation of two genes coding for rat fatty acid binding proteins. J Biol Chem 260 : 1995-8.

3) Suruga K, Mochizuki K, Kitagawa M, Goda T, Horie N, Takeishi K, Takase S (1999) Transcriptional regulation of cellular retinol-binding protein, type II gene expression in small intestine by dietary fat. Arch Biochem Biophys 362 : 159-66.

4) Mochizuki K, Suruga K, Kitagawa M, Takase S, Goda $\mathrm{T}$ (2001) Modulation of the expression of peroxisome proliferator-activated receptor-dependent genes through disproportional expression of two subtypes in the small intestine. Arch Biochem Biophys 389 : $41-8$.

5) Freeman TC, Wood IS, Sirinathsinghji DJ, Beechey RB, Dyer J, Shirazi-Beechey SP (1993) The expression of the $\mathrm{Na}^{+}$/glucose cotransporter (SGLT1) gene in lamb small intestine during postnatal development. Biochim Biophys Acta 1146 : 203-12.

6) Shu R, David ES, Ferraris RP (1997) Dietary fructose enhances intestinal fructose transport and GLUT5 expression in weaning rats. Am J Physiol 272 : G446-53.

7) Honma K, Mochizuki K, Goda T (2007) Carbohydrate/ fat ratio in the diet alters histone acetylation on the sucrase-isomaltase gene and its expression in mouse small intestine. Biochem Biophys Res Commun 357 : 1124-9.

8) Kishi K, Tanaka T, Igawa M, Takase S, Goda T (1999) Sucrase-isomaltase and hexose transporter gene expressions are coordinately enhanced by dietary fructose in rat jejunum. J Nutr 129 : 953-6.

9) Fraichard A, Chassande O, Plateroti M, Roux JP, Trouillas J, Dehay C, Legrand C, Gauthier K, Kedinger $\mathrm{M}$ et al. (1997) The $\mathrm{T}_{3} \mathrm{R} \alpha$ gene encoding a thyroid hormone receptor is essential for post-natal 
development and thyroid hormone production. EMBO J 16 : 4412-20.

10) Douard V, Cui XL, Soteropoulos P, Ferraris RP (2008) Dexamethasone sensitizes the neonatal intestine to fructose-induction of GLUT5 transport function. Endocrinology 149 : 409-23.

11) Schubeler D, MacAlpine DM, Scalzo D, Wirbelauer C, Kooperberg C, van Leeuwen F, Gottschling DE, O’Neill LP, Turner BM et al. (2004) The histone modification pattern of active genes revealed through genome-wide chromatin analysis of a higher eukaryote. Genes Dev 18 : 1263-71.

12) Yang XJ (2004) Lysine acetylation and the bromodomain: A new partnership for signaling. Bioassays 26 : 1076-87.

13) Mochizuki K, Mochizuki H, Kawai H, Ogura Y, Shimada M, Takase S, Goda T (2007) Possible role of fatty acids in milk as the regulator of the expression of cytosolic binding proteins for fatty acids and vitamin A through PPAR $\alpha$ in developing rats. J Nutr Sci Vitaminol (Tokyo) 53 : 515-21.

14) Mochizuki K, Suruga K, Sakaguchi N, Takase S, Goda $\mathrm{T}$ (2002) Major intestinal coactivator p300 strongly activates peroxisome proliferator-activated receptor in intestinal cell line, Caco-2. Gene 291 : 271-7.

15) Mochizuki K, Kawai H, Mochizuki H, Shimada M, Takase S, Goda T (2008) Fatty acids in component of milk enhance the expression of the cAMP-responseelement-binding-protein-binding protein $(\mathrm{CBP}) / \mathrm{p} 300$ gene in developing rats. Br J Nutr 99 : 481-6.

16) Mochizuki K, Yagi E, Sakaguchi N, Mochizuki H, Takabe S, Kuranuki S, Suzuki T, Shimada M, Goda T (2007) The critical period for thyroid hormone responsiveness through thyroid hormone receptor isoform $\alpha$ in the postnatal small intestine. Biochim Biophys Acta 1770 : 609-16.

17) Yorita S, Mochizuki K, Goda $T$ (2009) Induction of histone acetylation on the sucrase-isomaltase gene in the postnatal rat jejunum. Biosci Biotechnol Biochem 73 : 933-5.

18) Mochizuki K, Sakaguchi N, Goda $T$ (2007) Triiodothyronine $\left(\mathrm{T}_{3}\right)$ and fructose coordinately enhance expression of the GLUT5 gene in the small intestine of rats during weaning period. Biosci Biotechnol Biochem 71 : 1345-7.
19) Mochizuki K, Yorita S, Goda T (2009) Gene expression changes in the jejunum of rats during the transient suckling-weaning period. J Nutr Sci Vitaminol (Tokyo) 55 : 139-48.

20) Mochizuki K, Suruga K, Fukami H, Kiso Y, Takase S, Goda T (2006) Selectivity of fatty acid ligands for PPAR $\alpha$ which correlates both with binding to cis-element and DNA binding-independent transactivity in Caco-2 cells. Life Sci 80 : 140-5.

21) Mochizuki K, Suzuki T, Goda T (2008) PPAR $\alpha$ and $\operatorname{PPAR} \delta$ transactivity and p300 binding activity induced by arachidonic acid in colorectal cancer cell line Caco-2. J Nutr Sci Vitaminol (Tokyo) 54 : 298-302.

22) Matosin-Matekalo M, Mesonero JE, Laroche TJ, Lacasa M, Brot-Laroche E (1999) Glucose and thyroid hormone co-regulate the expression of the intestinal fructose transporter GLUT5. Biochem J 339 (Pt 2): 233-9.

23) Boucher MJ, Rivard N (2003) Regulation and role of brush border-associated ERK1/2 in intestinal epithelial cells. Biochem Biophys Res Commun 311: 121-8.

24) Mochizuki K, Sakaguchi N, Takabe S, Goda T (2007) De-phosphorylation of TR $\alpha$ - 1 by p44/42 MAPK inhibition enhances T(3)-mediated GLUT5 gene expression in the intestinal cell line Caco-2 cells. Biochem Biophys Res Commun 359 : 979-84.

25) Takabe S, Mochizuki K, Goda T (2008) De-phosphorylation of GR at Ser203 in nuclei associates with GR nuclear translocation and GLUT5 gene expression in Caco-2 cells. Arch Biochem Biophys 475 : 1-6.

26) Suzuki T, Mochizuki K, Goda T (2008) Histone H3 modifications and Cdx-2 binding to the sucrase-isomaltase (SI) gene is involved in induction of the gene in the transition from the crypt to villus in the small intestine of rats. Biochem Biophys Res Commun 369 : 788-93.

27) Honma K, Mochizuki K, Goda T (2009) Inductions of histone $\mathrm{H} 3$ acetylation at lysine 9 on SGLT1 gene and its expression by feeding mice a high carbohydrate/ fat ratio diet. Nutrition $25: 40-4$.

28) Honma K, Mochizuki K, Goda T (2008) Acute induction of histone acetylation on the jejunal sucrase-isomaltase gene by dietary fructose. Br J Nutr 100 : 698-702. 


\title{
Review
}

\section{Regulation of Small-intestinal Gene Expression by Chromatin Remodeling Factors} (2009 JSNFS Young Investigator Award)

\author{
Kazuki Mochizuki ${ }^{*, 1}$
}

(Received September 17, 2009; Accepted October 14, 2009)

\begin{abstract}
Summary: Jejunal expression of the genes for the vitamin A-binding protein CRBPII and the fatty acid-binding protein L-FABP is induced during the middle of the suckling period, whereas that of the genes for disaccharidase sucrase-isomaltase and the fructose transporter GLUT5 are induced from the middle to late suckling period. In this study, we demonstrated that induction of the CRBPII and L-FABP genes is mediated by one of the nuclear receptors, PPAR $\alpha$, whereas induction of the GLUT5 gene is regulated by the nuclear receptors for thyroid hormone (TR $\alpha-1)$ and glucocorticoid hormone (GR). Furthermore, we found that the signals of nutrients/hormones induce histone acetylation and binding of one of the chromatin remodeling factors, $\mathrm{CBP} / \mathrm{p} 300$, to the upstream/ transcriptional regions of these genes. Our results suggest that nutrients/hormones regulate the expression of jejunal genes, not only as activators of nucler transcriptional factors, but also as key factors for changing the remodeling of chromatin.
\end{abstract}

Key words: nutrients, jejunum, nuclear transcriptional factors, histone acetylation, chromatin remodeling factors

* Corresponding author (E-mail : wazyumochi@hotmail.com)

1 School of Food and Nutritional Sciences, The University of Shizuoka, 52-1 Yada, Shizuoka 422-8526, Japan 